\title{
ADHERENCE TO SIX MONTHS OF INSTRUCTED MINIMALIST AND BAREFOOT RUNNING TRAINING
}

\author{
ADESÃO A SEIS MESES DE TREINAMENTO INSTRUIDOO DE CORRIDA MINIMALISTA E DESCALÇA
}

ADHESIÓN A SEIS MESES DE ENTRENAMIENTO INSTRUIDO DE CARRERA MINIMALISTA Y DESCALZA

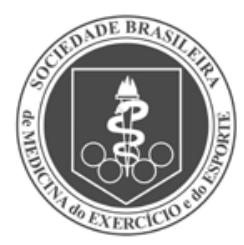

Artigo Original Original ARTICLE Artículo Original
Ana Paula da Silva Azevedo' (Educador Físico)

Clara Nóbrega' (Educador Físico)

Alberto Carlos Amadio'

(Educador Físico)

Júlio Cerca Serrão' (Educador Físico)

1. Universidade de São Paulo, Escola de Educação e do Esporte,

São Paulo, SP, Brasil.

\section{Correspondence:}

Professor Mello Moraes Avenue, 65, Butantã, São Paulo, SP, Brasil. 05508-030 +55 11 3091-3184.

anaazevedo@usp.br

\begin{abstract}
Introduction: The interest in minimalist and barefoot running is growing continuously. However, there is no data on how many runners drop out during this process. Objective: To describe the adhesion and dropout rates of a six-month instructed training program based on barefoot and minimalist footwear running. Methods: Thirty-four recreational runners participated in the study: 20 runners started the race training barefoot, while 14 runners were involved in training with minimalist footwear. Adhesion to intervention programs was evaluated through training spreadsheets and recording attendance at training sessions, while dropouts were evaluated at the end of training. A questionnaire was sent to participants who dropped out of the training, to obtain information related on why they had abandoned it. Results: Considering all participants ( $n=34), 41.2 \%$ of the runners completed six months with reduced plantar protection; $70 \%$ of all dropouts occurred in barefoot training; the main reasons for leaving the training were injury/pain (40\%) and lack of time/suitable place for training (40\%); and the majority of dropouts (50\%) occurred in the first month of training. Barefoot training $(n=20)$ showed $70 \%$ dropouts, $57.1 \%$ of them due to lack of time/suitable place for training; and $71.4 \%$ of the dropouts occurred in the first month of the intervention. The training with minimalist footwear $(n=14)$ had fewer dropouts (42.9\%) than the barefoot training, all of them due to injury/pain; $50 \%$ of them occurred in the third month of intervention. Conclusion: Dropouts usually occur at the beginning of training. Training involving barefoot running has more dropouts than training with minimalist footwear. Intervention programs lasting six months based on minimalist footwear/barefoot seems to have similar adhesion to other supervised exercise programs. The main reasons for dropping out are injury/pain and lack of time/suitable place to run.
\end{abstract}

Keywords: running; patient dropouts; life style; exercise.

\section{RESUMO}

Introdução: O interesse acerca da corrida minimalista e descalça cresce continuamente. Contudo, não há dados sobre a evasão de corredores nesse processo. Objetivo: Descrever a adesão e a evasão de um programa de seis meses de treinamento instruído baseado na corrida descalça e em calçados minimalistas. Métodos: Trintae quarto corredores recreacionais participaram do estudo: 20 corredores iniciaram o treinamento de corrida com os pés descalços, enquanto 14 se envolveram no treinamento com calçado minimalista. A adesão aos programas de intervenção foi verificada por intermédio de planilhas de treinamento e controle de presença nas sessões de treino, enquanto a evasão foi avaliada ao término do treinamento. Um questionário foi enviado aos participantes que saíram do treinamento, obtendo-se informações relacionadas ao abandono das intervenções. Resultados: Considerando-se todos os participantes ( $n=34$ ), 41,2\% dos corredores finalizaram os seis meses de treinamento com proteção plantar reduzida; $70 \%$ das evasões ocorreram no treinamento descalço; as principais razões para abandonar o treinamento foram lesão/dor (40\%) e ausência de tempo/local apropriado para o treinamento (40\%) e a maioria das desistências (50\%) ocorreu no primeiro mês de treinamento. O treinamento descalço ( $n=$ 20) apresentou $70 \%$ de evasão, sendo $57,1 \%$ devido à ausência de tempo/local apropriado para o treinamento; $71,4 \%$ da evasão ocorreu no primeiro mês de intervenção. $O$ treinamento de corrida com calçado minimalista $(n=14)$ apresentou menor evasão $(42,9 \%)$ que o treinamento descalço, sendo todas devido à lesão ou dor; $50 \%$ delas ocorreram no terceiro mês de intervenção. Conclusão: A evasão em geral ocorre no início do treinamento. A corrida descalça apresenta mais evasão do que a corrida com calçado minimalista. Os programas de intervenção que duram seis meses, baseados em calçado minimalista/pés descalços parecem ter adesão similar à de outros programas dirigidos de exercício. Os principais motivos para o abandono são lesão e dor e falta de tempo/local adequado para correr.

Descritores: corrida; pacientes desistentes do tratamento; estilo de vida; exercício.

\section{RESUMEN}

Introducción: El interés en la carrera minimalista y descalza crece continuamente. Sin embargo, no hay datos sobre la evasión de practicantes durante el proceso. Objetivo: Describir la adhesión y evasión de un programa de seis meses de entrenamiento instruido de carrera descalza y con calzado minimalista. Métodos: Treinta y cuatro corredores recreativos participaron en el estudio: 20 corredores comenzaron el entrenamiento en pies descalzos, mientras 14 hicieron el entrenamiento con el calzado minimalista. La adhesión a los programas de intervención 
se verificó a través de hojas de cálculo y control de la presencia en las sesiones de entrenamiento, mientras la evasión se evaluó al final del entrenamiento. Se envió un cuestionario a los participantes que abandonaron el entrenamiento para la obtención de información relacionada con el abandono de las intervenciones. Resultados: De todos los participantes $(n=34)$, el $41,2 \%$ de los corredores han completado seis meses de entrenamiento con protección plantar reducida; $70 \%$ de evasión se produjo en el entrenamiento descalzo; las principales razones para abandonar el entrenamiento fueron: lesión/dolor (40\%) y la falta de tiempo/lugar adecuado para el entrenamiento (40\%); la mayoría de abandonos (50\%) ocurrieron en el primer mes de entrenamiento. El entrenamiento descalzo $(n=20)$ mostró $70 \%$ de evasión, con $57,1 \%$ debido a la falta de tiempo/lugar adecuado para entrenamiento; $71,4 \%$ de la evasión se produjo en el primer mes de la intervención. La carrera con el calzado minimalista ( $n=$ 14) mostró evasión más baja (42,9\%) que el entrenamiento descalzo, todos los casos debiéndose a lesión o dolor; $50 \%$ de ellos se produjo en el tercer mes de la intervención. Conclusión: El abandono por lo general ocurre al comienzo del entrenamiento. La carrera descalza presenta más evasión que la carrera con calzado minimalista. Los programas de intervención con duración de seis meses y en base a carrera minimalista/descalza parecen que tienen evasión similar a otros programas de ejercicios supervisados. Las principales razones para el abandono son las lesiones y el dolor y la falta de tiempo y/o lugar adecuado para la carrera.

Descriptores: carrera; pacientes desistentes del tratamiento; estilo de vida; ejercicio.

\section{INTRODUCTION}

Running is one of the most important recreational and sport activities $^{1,2}$. Despite footwear industry efforts to develop modern running shoes and protective elements to exercise, the incidence of running injuries is still high: about 30-80\%3,4. Running barefoot and/or in minimalist shoes have been suggested recently as an interesting training approach to prevent running related injuries ${ }^{5-8}$.

Running barefoot or in minimalist shoes that mimic this situation are considered as conditions in which external protection is minimal ${ }^{9,10}$, presenting similar mechanical behavior ${ }^{6}$ and being classified as minimal running. Evidences show the adoption of minimal running could be positive to reduce the mechanical load imposed to human body $^{5-8}$, what could prevent runners from some running-related injuries. As result, many runners have been interested and encouraged to adopt this way of running ${ }^{11-13}$.

According to recent surveys, most runners (about 80\%) are interested about running barefoot or in minimalist shoes ${ }^{12,13}$. Indeed, the primary motivating factor for being interested or to adopt barefoot running/minimalist shoes has been to prevent injuries ${ }^{12,13}$. In contradiction, the most prevalent barrier in transitioning to minimal running is fear of developing injuries. This evidence is reflected in practice: only about $22 \%$ of runners had previously tried barefoot running ${ }^{13}$, while about $31 \%$ had tried running in minimalist shoes ${ }^{12,13}$.

The interest about adaptation to barefoot condition and minimalist shoe grows continuously. However, there is no data about how many runners drop out in this process. These data, which exists for other movements and training strategies, do not exist for minimal running. Minimalist and barefoot running training programs are uncommon and long-term researches concerning minimal running are rare. Indeed, the lack of drop-out data makes difficult to elaborate instructed intervention programs based on minimal running, as well as to plan supervised training sessions using this strategy. Unfortunately, most runners who implemented minimal running in their training did the transition without professional instructions ${ }^{13}$. To the best of our knowledge, few researches have investigated minimal running as training approach. One example is McCarthy et al. ${ }^{14}$, who proposed 12 weeks of running training in conventional and minimalist shoes. Authors observed similar drop-out for control group (running conventional shoes) and experimental group (running in minimalist shoes), about of $36.7 \%$, and the main reason for dropping out was injury. However, training period was short (three months) and barefoot running was not tested as training strategy. Therefore, the adhesion to instructed barefoot and minimalist running training and the reasons for dropping out from a minimal training remain unclear.

Thus, the purpose of this study was to describe the adhesion to and the dropouts from six-month instructed interventions based on running training in minimalist shoe and barefoot condition. Another purpose of the study was to exam the time and reasons for dropping out from minimal running instructed training.

\section{MATERIALS AND METHODS}

A six-month instructed intervention based on minimal running was proposed and followed. In total, 34 recreational runners (25 men and nine women, $30.8 \pm 6.8$ years, $72.6 \pm 11.0 \mathrm{~kg}, 1.73 \pm 0.08$ $\mathrm{m})$ participated in training. The intervention was divided into two training programs executed at the same time. One program was implemented through six-month barefoot running training, while the other program was done by the use of minimalist shoe in the six-month running training.

Twenty recreational runners ( 13 men and seven women, $33.2 \pm 6.4$ years, $72.6 \pm 14.2 \mathrm{~kg}, 1.72 \pm 0.11 \mathrm{~m}$ ) initiated the barefoot instructed training. Participants reported 5.6 years of experience in regular running training (0.5 - 22 years), weekly volume of $44.2 \mathrm{~km}$ (25 - 100 kilometers per week) and 4 training sessions per week ( 3 - 5 sessions per week).

Minimalist shoe instructed training began with 14 recreational runners (12 men and two women, $28.4 \pm 7.3$ years, $72.7 \pm 7.8 \mathrm{~kg}, 1.74 \pm 0.06$ $\mathrm{m})$. Participants had 7.7 years of experience in regular running training (1 - 25 years), 88.3 km of weekly volume (60 - 120 kilometers per week) and four training sessions per week (three - five sessions per week).

Participants did not have suffered any structural injury in the last 12 months and did not have any previous experience in barefoot running or minimalist shoes. All participants were informed about the study and signed a consent form. The study protocol was approved by the local ethics committee (School of Physical Education and Sport, University of São Paulo, № 17816613.9.0000.5391).

During the six months of intervention, participants ran progressively at the barefoot condition. In the first month, participants were instructed to walk 5\% of their weekly training volume in soft surfaces. From second till sixth month, participants started to progressively run barefoot: they evolved gradually from $5 \%$ to $30 \%$ of their weekly training volume being performed without shoes during this period. Also, participants were requested to mix soft and harder surfaces in their training. Barefoot running training should be performed three times per week. The participants kept their normal running training routine, 
using conventional running shoes in the remaining weekly volume, while they were involved in this research.

Three fitted pairs of shoes from New Balance ${ }^{\circledR}$ were given to each participant to mediate the intervention: a conventional running shoe, a "medium" minimalist shoe and a "low" minimalist shoe.

Conventional running shoe used was the NB 759 and it presents absolute heel height of $45 \mathrm{~mm}$, has $18 \mathrm{~mm}$ of heel-forefoot offset and weighs $280 \mathrm{~g}$. The NB 890 was the "medium" minimalist shoe adopted and it presents intermediate values of absolute heel height ( $40 \mathrm{~mm}$ ), heel-forefoot offset $(12 \mathrm{~mm})$ and weight $(250 \mathrm{~g})$ when compared to conventional shoe and low profile minimalist shoes. The "low" minimalist shoe was the NB Minimus MR10BG, whose absolute heel height is $25 \mathrm{~mm}$, heel-forefoot offset is four millimeters and it weighs $209 \mathrm{~g}$.

All participants were instructed to perform three training sessions per week using a determined given pair of shoes, while they maintained their habitual weekly running distance and routine of training sessions. During the first and second months, participants were instructed to use the conventional shoes given. The "medium" minimalist shoe should be worn in the third and fourth months of intervention. Lastly, the "low" minimalist shoes should be adopted in the fifth and sixth months of training. All training sessions were supervised by the researchers.

Participation and adhesion to both interventions were evaluated through training spreadsheets and presence control. In the end of intervention period, the dropouts were evaluated. A questionnaire was sent by email to participants who abandoned interventions in order to access the reasons for dropping out the training.

Descriptive statistics and percentages were used to summarize the adhesion to interventions and the reasons for dropping out.

\section{RESULTS}

Considering both interventions together, of 34 participants who initiated minimal running instructed training, $41.2 \%(n=14)$ remained until the end of six months, occurring 20 dropouts in this period. Seventy percent of dropouts ( $n=14$ ) occurred in the barefoot intervention, while $30 \%$ $(n=6)$ was observed in minimalist shoe intervention. The most reported reasons for dropping out from minimal running training were injury/pain $(40 \%, n=8)$ and lack of time/appropriate place for training sessions (40\%, $\mathrm{n}=8$ ) (Figure 1). Fear of developing injury were also reported as a factor for interrupting training (Figure 1). Fifty percent $(n=10)$ of dropouts from minimal training (barefoot and minimalist shoe interventions together) occurred in the first month of training; five participants quitted minimal training between the second and third months, as well as occurred between fourth and fifth months (Figure 2).

Analyzing each intervention solely, 30\% of participants (6 of 20) finished the training period in barefoot intervention, occurring 14 dropouts. Lack of time/place for training sessions $(57.1 \%, n=8)$ and fear of developing

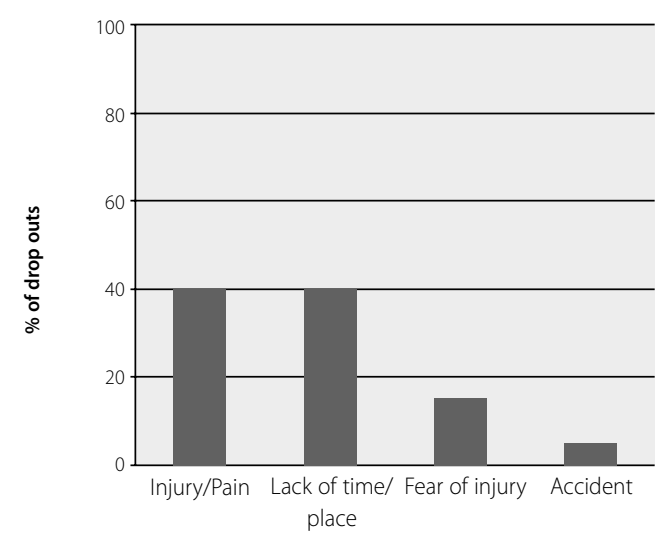

Figure 1. Reasons for dropping out minimal running training (barefoot and minimalist shoe training together, $n=34$ ).

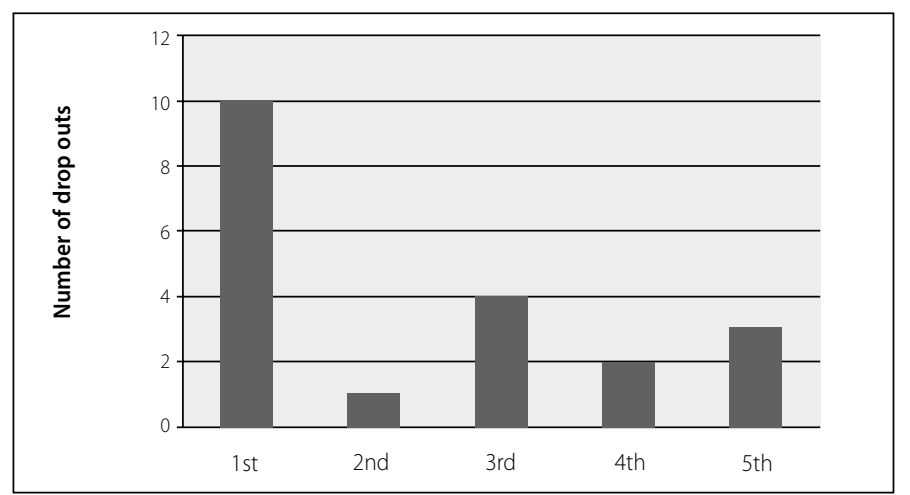

Figure 2. Number of dropouts for each month of minimal running training (barefoot and minimalist shoe training together, $n=34$ ).

injury $(21.4 \%, n=3)$ were reported as the main reasons to abandon barefoot training. Two participants quitted barefoot intervention due to injury/pain (14.3\%) and one participant suffered an accident. For barefoot training, 71.4\% $(n=10)$ of dropouts occurred in the first month of intervention.

In minimalist shoe intervention, about $57.1 \%$ (8 of 14 participants) persisted until the end of six months of training, occurring 6 dropouts. All participants who quitted minimalist training $(100 \%, n=6)$ reported injury/pain. Three of them (50\%) dropped out in the third month; one participant quitted the intervention in the fourth month and two runners abandoned training in the fifth month.

\section{DISCUSSION}

This is the first study to propose a long instructed intervention based on minimal running (barefoot and minimalist shoes), with standardized and supervised training. Moreover, our study is the first to evaluate adhesion to and dropouts from a minimal running intervention, as well as to describe the time and reasons of dropping out from a barefoot/minimalist running training.

Data indicates about half of participants who initiate a six-month instructed intervention mediated by minimal running (barefoot and minimalist shoes) adhere to training till the end of period. Considering evidences that many runners have fear to develop injuries during minimal running ${ }^{12,13}$, a considerable number of dropouts would be expected. Surprisingly, results indicate the dropouts in the present study are according to the percentage found for others supervised exercise programs. The typical dropout rate from different types of supervised exercise programs reported by literature is around $50 \%{ }^{15-20}$. Considering barefoot and minimalist shoe interventions together, our study observed $58.8 \%$ of dropouts from an instructed minimal running training.

Minimalist shoe training also presented a dropout similar to that reported for other exercise programs (42.9\%). On the other hand, a higher number of dropouts was observed for barefoot training: 70\% of runners dropped out abandoned barefoot running. This result may reflect a higher discomfort in the adoption of barefoot running and greater concern about protection of plantar surface. Although minimalist shoe serves to mimic the mechanical condition imposed by barefoot condition, the small protection offered by this shoe to plantar surface may diminish sore and discomfort in this region. This fact could favor the maintenance of participants in the training program.

Nevertheless, fear of developing injury or discomfort were not the most reported motivating factor for dropping out from the instructed minimal running intervention. In opposition to literature ${ }^{12,13}$, the main reason found to leave minimal running training was the occurrence of injury and/or pain, and the lack of time and/or an appropriate place to run barefoot or in minimalist shoes. The concern about an appropriate place to perform minimal training may carry an implicit insecurity and/or discomfort in maintaining these training strategies, also. Forty percent of runners who abandoned minimal running training suffered 
injury and/or pain. Such data corroborate to studies about injuries in novice minimal runners: cases of stress fractures in lower limbs have been reported in runners who had been used barefoot/minimalist shoe as training strategy ${ }^{21-23}$.

However, it is important to highlight these injuries are also according to the high incidence of running related injuries reported in the literature $^{4}$. Due to study design, it is not possible to conclude if the injuries are attributable to minimal running and an excessive risk for practitioner, or if these injuries just reflect the common incidence of injuries observed in runners. Further studies are needed to investigate this issue.

Unexpectedly, difficulties in getting time and/or place for training were the most prevalent reason for dropping from barefoot instructed training, while all dropouts from minimalist shoe running program were due to injuries. A possible explanation to this result could be the higher weekly volume of running observed in the participants of minimalist shoe intervention. Even though total load of minimal training had been low and well controlled, participants of minimalist shoe training presented an average of total weekly volume twice of that observed for participants in barefoot training. This factor could expose them more than runners with lesser running weekly volume to injury risk².

In general, half of participants abandoned the instructed minimal intervention in the first month of running training. Barefoot training had $50 \%$ of dropouts occurring in the first month. This result can imply the discomfort and difficulties of adapting to barefoot running, considering few injuries were observed in this group. In minimalist shoe training, the third month presented the higher number of dropouts (50\%). A possible explanation is the use of a conventional running shoe in the first and second months of training, with some characteristics similar to their habitual shoe. On the other hand, this result allows speculating that minimalist shoe training can be easier for runners to adapt and keep training, but can also be related to chronicle injuries, as reported by some studies ${ }^{21,23}$.

Some limitations are intrinsic to study design and must be acknowledged. For a descriptive study, our sample is a very small proportion of population and it is not wide enough to represent all community of runners. But, it is important to highlight the study is linked to an intervention program of running, what naturally restricts our coverage. Additionally, the participants selected to the study are recreational runners. Thus, results must be interpreted and extrapolated cautiously to different populations and contexts.

\section{CONCLUSION}

A six-month instructed intervention based on barefoot and minimalist shoe running has similar adhesion of other supervised exercise programs. The most common reasons for dropping out from minimal training are the occurrence of injury and/or pain, and the lack of time and/or an appropriate place to run barefoot and in minimalist shoes. Barefoot training showed higher number of dropouts than minimalist shoe training, concentrated in the first month of training, while minimalist training dropouts usually occurred in the middle of intervention. Results suggest barefoot and minimalist shoes are practicable strategies to implement minimal running training.

\section{ACKNOWLEDGEMENTS}

The authors would like to acknowledge the University of São Paulo (USP), which gave financial support to this research by the "USP in 2016 Olympic Games Program". We also thank New Balance Co. from Brazil for donating the shoes used in this study to the University of São Paulo. None of these funding sources had any role in the research design, as well as in its analysis and publication. The authors would like to thank the subjects for their participation in this study.

Additionally, authors acknowledge CAPES for financial support to publish this manuscript.

All authors have declared there is not any potential conflict of interests concerning this article.

CONTRIBUIÇÕES DOS AUTORES: Cada autor contribuiu individual e significativamente para o desenvolvimento do manuscrito. APSA (0000-0003-4866-145X)* e CN (0000-0001-5087-4572)* foram os principais contribuintes na redação do manuscrito e aplicação da intervenção. ACA (0000-0002-2527-2163)* e JCS (00000002-3646-3387)* supervisionaram o treinamento. Todos os autores avaliaram os dados e contribuíram com a análise estatística. APSA e CN realizaram a pesquisa bibliográfica, enquanto ACA e JCS realizaram a revisão do manuscrito. Todos os autores contribuíram com o conceito intelectual do estudo. *Numero ORCID (Open Researcher and Contributor ID).

\section{REFERENCES}

1. Fredericson M, Misra AK. Epidemiology and aetiology of marathon running injuries. Sports Med. 2007;37(4-5):437-9.

2. Rasmussen $\mathrm{CH}$, Nielsen RO, Juul MS, Rasmussen S. Weekly running volume and risk of running-related injuries among marathon runners. Int J Sports Phys Ther. 2013;8(2):111-20.

3. Messier SP, Legault C, Schoenlank CR, Newman JJ, Martin DF, DeVita P. Risk factors and mechanisms of knee injury in runners. Med Sci Sports Exerc. 2008:40(11):1873-9.

4. van Gent RN, Siem D, van Middelkoop M, van Os AG, Bierma-Zeinstra SM, Koes BW. Incidence and determinants of lower extremity running injuries in long distance runners: a systematic review. $\mathrm{Br}$ J Sports Med. 2007;41(8):469-80

5. Lieberman DE, Venkadesan M, Werbel WA, Daoud Al, D'Andrea S, Davis IS, et al. Foot strike patterns and collision forces in habitually barefoot versus shod runners. Nature. 2010;463(7280):531-5.

6. Squadrone R, Gallozzi C. Biomechanical and physiological comparison of barefoot and two shod conditions in experienced barefoot runners. J Sports Med Phys Fitness. 2009:49(1):6-13.

7. Bonacci J, Saunders PU, Hicks A, Rantalainen T, Vicenzino BG, Spratford W. Running in a minimalist and lightweight shoe is not the same as running barefoot: a biomechanical study. Br J Sports Med. 2013:47(6):387-92

8. Williams DS 3rd, Green DH, Wurzinger B. Changes in lower extremity movement and power absorption during forefoot striking and barefoot running. Int J Sports Phys Ther. 2012;7(5):525-32.

9. De Wit B, De Clercq D, Aerts P. Biomechanical analysis of the stance phase during barefoot and shod running. J Biomech. 2000;33(3):269-78

10. Divert C, Mornieux G, Baur H, Mayer F, Belli A. Mechanical comparison of barefoot and shod running Int J Sports Med. 2005;26(7):593-8.

11. Lieberman DE. What we can learn about running from barefoot running: an evolutionary medical perspective. Exerc Sport Sci Rev. 2012;40(2):63-72.

12. Cohler MH, Casey E. A Survey of Runners' Attitudes Toward and Experiences With Minimally Shod
Running. PM R. 2015:7(8):831-5.

13. Rothschild CE. Primitive running: a survey analysis of runners' interest, participation, and implementation. J Strength Cond Res. 2012;26(8):2021-6.

14. McCarthy C, Fleming N, Donne B, Blanksby B. 12 weeks of simulated barefoot running changes foot-strike patterns in female runners. Int J Sports Med. 2014;35(5):443-50.

15. McAuley E, Lox C, Duncan TE. Long-term maintenance of exercise, self-efficacy, and physiologica change in older adults. J Gerontol. 1993:48(4):P218-24.

16. King AC, Taylor CB, Haskell WL, Debusk RF. Strategies for increasing early adherence to and long-term maintenance of home-based exercise training in healthy middle-aged men and women. Am J Cardiol. 1988;61(8):628-32.

17. Williams P, Lord SR. Predictors of adherence to a structured exercise program for older women. Psycho Aging. 1995;10(4):617-24.

18. Wilbur J, Michaels Miller A, Chandler P, McDevitt J. Determinants of physical activity and adherence to a 24-week home-based walking program in African American and Caucasian women. Res Nurs Health. 2003;26(3):213-24.

19. Dishman RK, Dunn AL Exercise adhesion: its impact on public health. Champaign, IL: Human Kinetics Books; 1988.

20. Dishman RK. Increasing and maintaining exercise and physical activity. Behav Ther. 1991;22:345-78.

21. Ridge ST, Johnson AW, Mitchell UH, Hunter I, Robinson E, Rich BS, Brown SD. Foot bone marrow edema after a 10-wk transition to minimalist running shoes. Med Sci Sports Exerc. 2013;45(7):1363-8.

22. Giuliani J, Masini B, Alitz C, Owens BD. Barefoot-simulating footwear associated with metatarsal stress injury in 2 runners. Orthopedics. 2011;34(7):e320-3.

23. Cauthon DJ, Langer P, Coniglione TC. Minimalist shoe injuries: three case reports. Foot (Edinb). 2013;23(2-3):100-3 